\title{
The Macabre on the Margins: A Study of the Fantastic Terrors of the Fin de Siècle
}

\section{ABSTRACT}

With a view to discussing an important three-faceted example of marginality in literature whereby terror, the literary Fantastic and the fin de siècle period are understood as interconnected marginalia, this paper examines works such as Guy de Maupassant's “Le Horla” and H. Rider Haggard's She from an alternative critical perspective to that dominating current literary discourse.

It demonstrates that in spite of the dominant associations of fantastic literature with horror, terror, as the marginal and marginalized fear of the unknown, with its uncanny, sublime and suspenseful qualities, holds a definitive presence in fin de siècle fantastic texts. Literary analysis of the chosen texts registers significant examples of the importance of terror to fantastic writing, and as such functions to extract an "aesthetics of sublime terror" from the margins of critical studies of this often macabre literary mode.

\section{Abstract}

THE OLDEST and strongest emotion of mankind is fear, and the oldest and strongest kind of fear is fear of the unknown. H.P. Lovecraft "Supernatural Horror in Literature"

The terrifying and sublime elements of fantastic literature are all too often marginalized in favour of a focus on the horrible and the horrific. From 
this perspective this paper will analyze a three-faceted example of marginality in literature whereby terror, the literary Fantastic and the fin de siècle period are understood as interconnected marginalia. It will necessarily explore the implications of the aesthetic concept of terror in relation to fantastic literature at the borderline period of the turn of the twentieth century. With a focus on the marginal space between terror and horror, Guy de Maupassant's "Le Horla” and H. Rider Haggard's She will be analyzed in order to discuss the prevalence of both the sublime and fear of the unknown in this macabre mode of fiction.

\section{TERROR AND HORROR}

Terror is understood in this context as an experience that can be clearly differentiated from horror, dread, anxiety and other experiences of fear. Recalling the ideas of Edmund Burke and Ann Radcliffe, it can be argued that terror is an experience of fear that is bound by suspense and hesitation. Importantly, the fear experience of terror, rather than exposing the object of fear, is suggestive of unimaginable horrors. The imagination is stimulated at the concealed possibility of the grotesque, and it is in obscurity and hesitance that terror finds its power. This results in a state of suspension between simultaneous fear and fascination in the subject. As Devendra Varma so aptly put it, "the difference between Terror and Horror is the difference ... between the smell of death and stumbling against a corpse" (130). And here, in the suspenseful state aroused by fear of the unknown, we find the most potent link between terror and the fantastic which itself has been defined as a genre bound by an experience of hesitance. According to Tzvetan Todorov, the fantastic is effectively "that hesitation experienced by a person who knows only the laws of nature, confronting the supernatural event" (25).

Terror is, according to Radcliffe, in her early $19^{\text {th }}$ century essay "On the Supernatural in Poetry," a route to sublime experience for this very reason, and was, as such, promoted as the prime focus for supernatural writing. The so-called "Mother of Gothic fiction" espouses the somewhat Romantic view that terror, because of its obscurity, has the ability to arouse and stimulate the sublime faculties of the imagination. Furthermore, she claims that when the object of fear is revealed, terror is evaded and the sublime feeling is lost: "now, if obscurity has so much effect on fiction, what must it have in real life, when to ascertain the object of our terror, is frequently to acquire the means of escaping it" (Radcliffe). Edmund Burke had already laid the foundations for this approach to the sublime in stating in his philosophical enquiry that "terror is in all cases whatsoever, either more openly or latently, the ruling principle of the sublime ... [and] is 
productive of the strongest emotion which the mind is capable of feeling” (86). Thus, terror is resultantly an enigmatic experience that is distinguishable as a subjective response to the unrepresentable and its power in supernatural writing can be apprehended in the earliest of nineteenth century fantastic tales.

Horror on the other hand, (and without relegating it to an inferior position by any means), is an experience of fear in which the grotesque object finds representation, and as such it has a very different impact on the imagination of the subject. Where terror, aroused by the unknown causes the imagination to expand, horror, provoked by the known or presented object, is associated with processes such as recoiling, abjection, and repulsion and the physical symptoms of fear. According to Gina Wisker, horror "names and dramatizes that which is otherwise unthinkable, unnamable, indefinable and repressed" (9). As a fearful response generated in literature, it may be seen as being positioned on the other side of the margin to that occupied by terror. And the marginal space between is the space occupied by the representational capacity of the imagination and the aesthetic sensibility of the subject. ${ }^{1}$ Wisker, in her comprehensive outline of horror fiction, which covers Beowulf through to twenty first century horror film, claims that "horror is located both in the real and in the nightmarish imaginary" (2). This is significant in that it highlights the very real and everyday occurrences of horrific events but also the playing out of horrific fantasies by the unconscious in response to fear of such events. Furthermore, she adds that horror "embodies that of which we cannot speak, our deep-seated longings and terrors ... and once they have been acted out, they are managed. Order is restored" (2). Horror is effectively a dramatization of terror, that fear of the unknown and unrepresentable, by creating and representing various fantasized objects of fear, more often than not through the creation of some sort of monstrous body.

Furthermore, while horror in literature is a limited form, if one agrees that, physically, there are a finite number of ways to scare the human reader or viewer, and additionally if one agrees with Devendra Varma that "to describe is to limit-to suggest is to stimulate the reader's imagination by the intimation of terror beyond the compass of words" (103), terror is unlimited in that it deals with the unknown, the unrepresentable and the sublime. For this reason, sublime fear has been associated by David Sadner with fantastic literature, which he defines as "a discourse of the sublime

1 Terror is linked to the sublime as discussed in Kant's Critique of Aesthetic Judgement, wherein the resultant experience of simultaneous pleasure and displeasure are seen as the result of a conflict of reason as it comprehends the sublime, and imagination as it fails to "re-present it" (24-26). 
in literature" (Fantastic in Literature 316). Referring to Addison's Pleasures of the Imagination and "the fairy way of writing" which Sadner reads as an $18^{\text {th }}$ century working definition of the fantastic, he also claims that in "both Romantic poetry and fantastic literature the imagination reaches beyond its grasp in a movements towards transcendence" (Fantastic Sublime 50). I would argue that it is in the pursuits of terror that the fantastic achieves this Romantic ideal and that terror, particularly in the fin de siècle fantastic, is a potent and defining narrative force.

The distinctions between horror and terror, as outlined above, however, are often neglected in studies of the literary fantastic and the Gothic anxieties that it so often pursues. Terror as an aesthetic experience is as such marginalized in favour of the more overt examples of horror and the horrific, which in much literary criticism have been placed at the centre of studies of the literary fantastic. At this point it should be stressed that it is not the aim of this study to suggest that authors of the fantastic are aware of these aesthetic and psychological distinctions between terror and horror. In fact, it is quite clear from most fantastic and Gothic texts that the terms "terror" and "horror" are often used within narrative interchangeably. However, beyond the language of these narratives, on the levels of structure, plot and metaphor, there is certainly evidence of a discernable marginal space between fear of the known or "presentable," and fear of the unknown and "unrepresentable," and it is upon this difference that this argument is based. With a focus on terror then, as fear of the unknown we can gain new perspectives on the fears generated in fantastic writing of the fin de siècle period linking the hesitation experienced in fantasticism to the hesitation experienced in the terror aroused by the same literature.

\section{ThE FANTASTIC}

To reiterate Todorov, the fantastic is "that hesitation experienced by a person who knows only the laws of nature, confronting the supernatural event." Significantly, considering the fantastic as such would imply that it is based on fearful uncertainty about the nature of reality. It is a literature of the impossible as C.S. Lewis points out in his Experiment in Criticism, defining the fantastic as "any narrative that deals with impossibles or preter-naturals" (50). With regards to this approach, the fantastic is linked directly to the sublime as interpreted by cultural theorist, Slavoj Žižek. According to Žižek, the sublime is "paradox of an object which, in the very field of representation, provides a view, in a negative way of the dimension of what is unrepresentable"; it is that which may allow us to "experience the impossibility of the thing" (203). The hesitation and impossibility that characterizes the fantastic may, therefore, be regarded as being closely as- 
sociated, as Sadner has pointed out, to the transcendence of the real and the encounter with the sublime other.

From this point, most critics would agree that the fantastic is most appropriately linked to periods in which accepted reality is brought under scrutiny, such as phases of political instability, or times of cultural turn. ${ }^{2}$ It is a mode of literature in which the margins between the possible and the impossible are blurred and as such is defined by the experience of hesitation and ambiguity. Todorov furthers this idea by suggesting that in the fantastic, there is also a blurring of the margins separating the psychological and the supernatural in terms of reader approach to the "marvellous" tale. This ties the fantastic firmly to the fin de siècle period as a pivotal era in terms of literary development. Much cultural unease was brought about at this liminal time by the dawn of psychoanalytic theory. Re-emerging awareness of the unknown and unknowable limits of the human psyche led to studies that eventually coined the term psychoanalysis in 1897. As a result, the seemingly deviant concepts of sexual desire, instinct, aggression and hysteria were transformed into the most potent of literary enquiries. The fear of the unknown, arguably propelled the literary fantastic toward representations of related cultural terrors, in British society in particular. We see this in British fiction that deals with issues to do with the beginnings of the decline of the British Empire which brought with it fear of colonial otherness; and with issues related to developments in technology, science and medicine. Similarly, studies in physiognomy and criminal anthropology inspired such works as Dr. Jekyll and Mr. Hyde and The Island of Dr. Morean. Such stories, while dealing with cultural fears, related those fears to the interiority of evil and "otherness" and readily captured the imagination of readers now placed in a world diminishing in terms of truth and authority. So at the end of the $19^{\text {th }}$ century, the fantastic reached a peak, and responding to social and cultural fears and anxieties it offered an encounter with sublime otherness through the experience of terror. And from this point it continued as a literature of alienation, existing as David Punter states in his critical work on the Gothic mode, on "the borderland of culture" (196).

The fantastic and "horror" have long been conceptually interlinked. This relationship primarily has to do with the fearful confrontation with the impossible and, or supernatural that the fantastic involves and also to do with the carnival aspect of horror which offers readers, among other things, "titillating exercises in reassurance" (Botting, The Gothic 134). Many critics have observed that we crave horror because of the aspect of

2 See Rein. A. Zondergeld's commentary on this, as translated to English in Johan$\operatorname{sen}(51)$. 
safety and the restoration of order that it involves. It is, as such, a popular transgressive mode which excessively crosses the margins of the acceptable, in the same movement, delineating those margins, establishing them perhaps even more firmly than before. The fantastic, in its concern with the marginalized and "othered" aspects of self and society is recognized as a subversive and as such marginal literary mode by many critics, most notably Rosemary Jackson in her book Fantasy: The Literature of Subversion. And this traversal of the limits of social and personal tolerance has often been related by those who connect the fantastic more directly to horror writing and film, to Bakhtin's carnivalesque, as a sort of licensed release from established rules of order and stability. In the fin de siècle period, the restoration of order was without doubt a fundamental occupation of much literary fiction. Although considered historically as a period of radical change, the late $19^{\text {th }}$ century produced a European society that was repressive; obsessed with the appearance of propriety, restraint and high morals. During this period the fantastic served a cathartic social function, offering often chaotic "other" worlds and figures to counterpoint the rigidly contained social order of the day.

But the chaos of horror was temporary and in many ways, the fantastic writing in English of the period, much of it, since classified as Gothic, utilized horror to reinforce societal conventions, most notably those upheld by the ideologies of patriarchy and Empire. Considering the fin de siècle and particularly the fantastic, one can identify clear examples of what Botting refers to as the "cautionary strategies" of such writing (Gothic 7) that are directly related to horror. Oscar Wilde's The Picture of Dorian Gray, for example, while seemingly a novel that is transgressive to the extremerepresenting the horrific object of fear, the painting of Dorian's corrupt soul-ends with the punishment and self-destruction of the narcissistic hero-villain. The horror figure of the monstrous double, in this way, serves to personify and therefore control the threat of "degeneration." Similarly, in Bram Stoker's Dracula, the diabolical vampiric Count, the ultimate antithesis of Victorian stability and values, is efficiently destroyed by the tandem forces of science, the modern Victorian man, and the New Woman. With respect to this, Kathleen Spenser has referred to Stoker's novel as "a classic example of the conservative fantastic" (209), noting that at the point when Dracula is killed, the represented alien element is expelled and the ordinary world is restored. Horror has passed, the object of fear has been represented and consequently limited, and so the subject returns to a position of safety.

Horror considered, what of terror, which can be read as a mode of fear in which there is no object to be represented or delimited, in which order is transgressed but not subsequently restored? As has been outlined, 
terror is a mysterious experience of the irrational, the weird and the uncanny simultaneously, and driven by suspense and tension, it offers unique creative space for writers of the fantastic. As such, the terrors of the fin de siècle fantastic, unlike its horrors, offer experiences of fear generated with a particular purpose. The sublime and imaginative consequences of terror effectively pose a mode of readerly and writerly experience that is transgressive in an unlimited sense. The recognition of the unknowable and unrepresentable object of fear is a transcendence of the margins that delimit external reality and society, offering the subject a route to the dark marginalia of the unconscious mind where all of its grotesque and uncanny qualities are at play. This unlimited quality of terror tenders a more anarchic literary experience, rebelling against order and reality and the limits of subjectivity.

For this reason it is intrinsically linked to the fantastic as a genre of hesitation, in its continued struggle with the order of the real and its resistance to marginalization and representation. In relation to this, H.P. Lovecraft claimed that "[a] tale is fantastic if the reader experiences an emotion of profound fear and terror, the presence of unsuspected worlds or powers" ("Supernatural Horror"). It is interesting to note that the frontman for twentieth century American horror writing would imply that terror is the primary fearful response associated with the literary fantastic in the periods during and preceding Lovecraft's own highly influential post-fin de siècle writing. However, this is less surprising when one considers the importance of the imagination and the sublime in Lovecraft's work and in particular in his aesthetics. He discloses something of this in his essay "Horror and the Supernatural in Literature":

The true weird tale has something more than secret murder, bloody bones, or a sheeted form clanking chains according to rule. A certain atmosphere of breathless and unexplainable dread of outer, unknown forces must be present; and there must be a hint, expressed with a seriousness and portentousness becoming its subject, of that most terrible conception of the human brain-a malign and particular suspension or defeat of those fixed laws of Nature which are our only safeguard against the assaults of chaos and the dxmons of unplumbed space. (Lovecraft)

In this commentary it is clear that Lovecraft prioritizes an atmosphere of "breathless and unexplainable dread of unknown forces," that sublime tension addressed in Radcliffe's essay which can arouse the imagination to a point of transcendence, here founded upon the hint of the supernatural and its potentially malignant otherness. This approach also is reminiscent of the literary theorizations of Edgar Allan Poe which practice similar examinations of the relationship between word and effect in 
writing. Poetry, Poe claimed, should begin with the consideration of the effect-the "innumerable effects or impression of which the heart, the intellect or the soul is susceptible" ("Philosophy") and standing by his manifesto, Poe remained, in all of his works, focussed on the power of poetic language to elevate the imagination.

\section{Guy de Maupassant: "La Peur," "Le Horla”}

Terror is inherently linked to the symbolic power of much fantastic writing. Yet, in terms of its aesthetic value in the fantastic text, terror is often undervalued and overlooked. Due to the cognitive and therefore memorable nature of horror, the sublime qualities of terror and its relationship to hesitance are perhaps easily neglected. In responding to this with a demonstration of how the fantastic, in relating to its context, utilizes terror as its primary aesthetic focus, the fin de siècle writing of Guy de Maupassant provides a number of illuminating passages. The 1887 short story "La Peur" offers an interesting focus to begin with. Encapsulating the marginal space between terror and the sublime, this uncanny story offers a distinctive handling of the unrepresentable. In an important moment in the story, the haunted protagonist, becoming increasingly paranoiac of some "sensed invisible power," describes how

a vague fear slowly took hold of me: fear of what? I had not the least idea. It was one of those evenings when the wind of passing spirits blows on your face and your soul shudders and knows not why, and your heart beats in a bewildered terror of some invisible thing, that terror whose passing I regret. (Maupassant, trans. Jameson 238)

This particular approach is similar in many respects to that which is found in what is generally considered de Maupassant's most accomplished fantastic tale "Le Horla" (which inspired, significantly, Lovecraft's own "The Call of Cthulhu"). In "Le Horla" we are offered a vision of sublime terror that is related to the Romantic notion of the invisible force of the wind. The protagonist, alone in his chamber and in a state of nervous excitement, becomes aware of this natural power as one of the many "unknowable forces, whose mysterious presence we have to endure" (Maupassant, trans. McMaster et al. 2). Later, in a fearful conversation with an enigmatic monk, he is enlightened to a sort of occult philosophy:

Do we see the hundred-thousandth part of what exists? Look here; there is the wind, which is the strongest force in nature. It knocks down men, and blows down buildings, uproots trees, raises the sea into mountains of water, destroys cliffs and casts great ships on to the breakers; it kills, 
it whistles, it sighs, it roars. But have you ever seen it, and can you see it?

Yet it exists for all that. (Maupassant, trans. McMaster et al. 9)

This is almost a direct representation of what Lovecraft outlines in his account of the essentials of the weird tale, mentioned earlier. The "certain atmosphere of breathless and unexplainable dread of outer, unknown forces is present," and the fixed laws or limits of nature have been suspended. Nature becomes much more than itself as a manifestation of a supernatural force.

The result in this tale is that the narrator's "confused and irresistible fear" is intensified. Heightened experiences such as the following proliferate:

I turned round suddenly, but I was alone. I saw nothing behind me except the straight, broad ride, empty and bordered by high trees, horribly empty; on the other side also it extended until it was lost in the distance, and looked just the same - terrible (Maupassant, trans. McMaster et al. 6).

According to Lovecraft, "this tense narrative ["Le Horla"] is perhaps without peer in its particular department" and de Maupassant's stories "are of the keenest interest and poignancy; suggesting with marvelous force the imminence of nameless terrors, and the relentless dogging of an ill-starred individual by hideous and menacing representatives of the outer blackness" ("Supernatural Horror"). Significantly, in relation to Lovecraft's comments, the word used by de Maupassant, "Horla," is a word play that has been equated with the French phrase hors la ("out there") and so we can divine that the centre of the work is based upon relating an excessive fear of that which is beyond or outside limits and unknown, in this case even unnamable. As such it is a story that is strongly focussed on terror of the unknown, a sublime terror.

Although this story is mentioned in Lovecraft's essay on "horror" in literature, it is the "tension" and hesitation of the tale that is regarded by Lovecraft as the source of its power; its suspense, essentially, its terror. In de Maupassant's account here of the experience of the Gothic sublime, we encounter the potential of terror in overwhelming the subject both physically and metaphysically through the evocation of the uncanny. According to David Morris, in his writings on the Gothic sublime,

the terror of the uncanny is released as we encounter the disguised and distorted but inalienable images of our own repressed desire ... [it is derived] not from something external, alien or unknown but—on the contrary-from something strangely familiar which defeats our efforts to separate ourselves from it. (307) 
Similarly, in Harold Bloom's critical writings we find an account of the uncanny as Freud's own theory of the sublime (Bloom; qtd. in Sadner, Fantastic Sublime 54). Enforcing this connection is a later passage from the story in which the narrator suspects the physical evidence of the supernatural force that is haunting him, to be of his own making:

It could surely only be I? In that case I was a somnambulist—was living, without knowing it, that double, mysterious life which makes us doubt whether there are not two beings in us-whether a strange and unknowable, and invisible being does not, during our moments of mental and physical torpor, animate the inert body, forcing it to a more willing obedience than it yields to ourselves. (Maupassant, trans. McMaster et al. 10)

This experience of the uncanny is an integral part of the terror involved. The object of fear is related to the unknown and unknowable aspects of the self, those which according to Freud are deeply familiar, most repressed, and while strikingly strange and unsettling, intrinsically a part of our identity (The Uncanny). For de Maupassant, this idea of the uncanny offers an interesting focus for his study of the psychological and mental deterioration of the individual, a common enough interest for writers and thinkers of the period. With close connections to the concept of the doppelgänger, it poses an investigation into specific terrors to do with identity, self knowledge and marginality.

According to Peter Cogman, de Maupassant's primary literary focus was "the limits of human knowledge, the idea that our senses impose a limited and inadequate view of reality" ("Le Horla"). His questioning of ideas of the real and the numinous are linked to a Gothic vision of the sublime, in which terror can evoke some experience of the esoteric and perhaps even transcendental. In "Le Horla," the terror of the narrator's experiences is more powerful and fearful than when the supernatural object is horrifically revealed, as in the following passage:

I spent a terrible evening yesterday. He does not show himself anymore, but I feel that He is near me, watching me ... and more terrible to me when He hides himself thus than if He were to manifest his constant and invisible presence by supernatural phenomena. (Maupassant, trans. McMaster et al. 23)

His later association of this unidentifiable "He" with the diabolical, which is destined to replace humanity on the earth, emphasizes this dark sublimity. The narrator's imagination goes out of control, transgressing limits to the point of no return and it is effectively this unknown being which takes over his narrative and leads to his paranoid committal of arson 
which destroys his home and the servants trapped inside. De Maupassant, through the build-up of the story generates an increasing suspense which mirrors the terrors of the protagonist in the mind of the reader and as such suggests that it is the power of terror and not horror that is truly worrying due to its close links to the mental deterioration of the subject in relation to the arousal of the hysterical state.

\section{Unrepresentable Terrors: H. Rider Haggard's She}

A very different exploration of the terrors of fantastic writing is offered in H. Rider Haggard's She. Offering a counter-point of sorts to de Maupassant's unidentifiable "He," She offers an intriguing example of the preoccupations of fin de siècle fiction in relation to terror. Considered by many critics as an example of the colonial fantastic, it outlines the adventures of a Cambridge educated classics scholar in an unexplored area of East Africa, where a marvellous immortal femme fatale Empress rules a society of slaves, her "Empire of the imagination," "by terror" (Haggard 179). Significantly, the novel offers a very clear positioning of Todorov's definition of the fantastic, offering a world in which there is a tense co-dependence between the magical/occult and the mundane reality of the "real" world. The intrusion of the unreal across the margins of empirical reality in the form of the uncanny is supported and documented with historical and archaeological referencing which contradicts the cognitive strategies undertaken by the academic protagonist resulting in intense and lingering fear and desire to uncover the mysteries at hand.

Significantly, in addition to this uncanny terror, according to Dale J. Nelson, She includes a comprehensive catalogue of the aural, visual and tactile experiences that are conducive to Burke's outline of the sublime, noting particularly the character's encounters with the violence of nature, the "savagery" of man and extreme darkness (Nelson 114). One such example is the narrator, Holly's misadventure in the dark labyrinth of She's caves; the obscurity and confusion, serving to intensify the suspense that leads up to the sublime unveiling of She in the twelfth chapter, half-way through the text. Nelson refers to the power of sublime terror in the example of the visual obscurity represented in She's first appearance in the novel. Holly is aware of her presence on some level, just as in the case of the narrator of Le Horla, but cannot see her.

Presently I clearly felt that somebody was looking at me from behind the curtains. I could not see the person, but I could distinctly feel his or her gaze, and, what is more, it produced a very odd effect upon my nerves. I was frightened, I do not know why. The place was a strange one, it is 
true, and looked lonely, notwithstanding its rich hangings and the soft glow of the lamps ... Minute grew into minute, and still there was no sign of life, nor did the curtain move; but I felt the gaze of the unknown being sinking through and through me, and filling me with a nameless terror, till the perspiration stood in beads upon my brow. (Haggard 145)

De Maupassant's unknown watcher is reinvoked in some sense here as the suspenseful feelings of "nameless terror" are aroused in the subject of both character and reader. Haggard continues:

At length the curtain began to move. Who could be behind it?-some naked savage queen, a languishing Oriental beauty, or a nineteenth-century young lady, drinking afternoon tea? I had not the slightest idea, and should not have been astonished at seeing any of the three. I was getting beyond astonishment. (145)

Interestingly, in this case, woman, in her ultimate form-intensely beautiful, wise and powerful, is feared as an unknowable other by the Victorian male protagonist. Sandra Gilbert comments on the effect of Haggard's portrayal of the terrible Queen as neither divine or demonic, angelic or monstrous. She is a marginal figure in that she exceeds categorization (124). She herself speaks of her own account and tells us: "Because I wait for him I love. My life has perchance been evil, I know not-for who can say what is evil and what good? - so I fear to die even if I could die" (153). Like other critics, Gilbert is focussed on the Empress's virginity and the purity of her love which opposes her monstrous passion and ruthless drive to gain the object of her desire. Due to this, "She," like a number of other female figures from fantastic literature, came to be cited in much psychoanalytic theory, notably those of Freud and Jung. Her symbolic power in relation to fear of otherness seems to lie behind this relatable to her own unnamability and marginality, being referred to throughout as "She" and is heightened by the introductory letter which frames the story, sent by Vincey to his son Leo before his suicide:

The unknown is generally taken to be terrible, not as the proverb would infer, from the inherent superstition of man, but because it so often is terrible. He who would tamper with the vast and secret forces that animate the world may well fall a victim to them. (Haggard 39)

The play between terror of the unknown and horror in the face of the grotesque is quite complex in the novel and possibly reaches a representative climactic moment at the point when Leo Vincey (Holly's charge) meets the ancient corpse of his doppelgänger, Kallikrates, his ancestor and the object of She's desire. 
With a sudden motion she drew the shroud from the cold form, and let the lamplight play upon it. I looked, and then shrank back terrified; since, say what she might in explanation, the sight was an uncanny one-for her explanations were beyond the grasp of our finite minds, and when they were stripped from the mists of vague esoteric philosophy, and brought into conflict with the cold and horrifying fact, did not do much to break its force. (Haggard 237)

What we have in this passage is a demonstration of terror and the uncanny in what is unknowable and incomprehensible to the human finite mind. This is in stark contrast to "the cold and horrifying fact" (238) that stretched out on the stone slab is a corpse that is Leo's exact double. The fear experienced by Leo, observed by Holly, is outlined as follows:

I turned to see what effect was produced upon Leo by the sight of his dead self, and found it to be one of partial stupefaction. He stood for two or three minutes staring, and said nothing, and when at last he spoke it was only to ejaculate- "Cover it up, and take me away." (238)

Here we have a clear demonstration of horror: the stupefaction of the imagination by the transgression of the limits of identity, in the representation of an ultimate fear, death. When the horrific has been presented and the grotesque has taken full effect, order is restored. The subject asks for the thing to be covered up and to be taken back to his temporary home.

Both of the textual examples here, from de Maupassant and Haggard respectively, register significant examples of the importance of terror to fantastic writing, particularly at that generative and liminal period of the fin de siècle. As such, they function to extract an aesthetics of sublime terror from the margins of critical studies of this macabre literary mode. This paper has sought to examine the implications of terror in the fin de siècle fantastic and as such, has demonstrated that in spite of the dominant associations of fantastic literature with horror, terror as the marginal and marginalized fear of the unknown, with its uncanny, sublime and suspenseful qualities holds a definitive presence in fin de siècle fantastic texts. It is a mode of fear that is closely related to the fantastic as a literary genre on the very grounds of the concept of marginality; terror and the fantastic being both bound by hesitation and the transgression of limits. This play on limits that we find in the fantastic terrors of the fin de siècle offers "a discourse of the sublime," to reiterate Sadner, an envisioning of the impossible realities that frighteningly occupy the most macabre margins of our imaginations. 


\section{WORKS CITED}

Botting, Fred. Gothic: The New Critical Idiom. London: Routledge, 1996. Print.

---. The Gothic: Essays and Studies. Cambridge: Brewer, 2001. Print.

Burke, Edmund. A Philosophical Enquiry into the Sublime and Beautiful. London: Penguin, 1998. Print.

Cogman, Peter. "Le Horla [The Horla]." The Literary Encyclopedia. 2004. Web. 18 Nov. 2010.

Freud, Sigmund. The Uncanny. Trans. David McLintock. London: Penguin, 2003. Print.

Gilbert, Sandra M. "Rider Haggard's Heart of Darkness." Coordinates: Placing Science Fiction and Fantasy. Ed. E.S. Rabkin, G.E. Slusser, and R. Scholes. Carbondale: Southern Illinois UP, 1983. 124-38. Print.

Haggard, H. Rider. She. London: Penguin, 2004. Print.

Jackson, Rosemary. Fantasy: The Literature of Subversion. London: Methuen, 1981. Print.

Johansen, Ib. "Shadows in a Black Mirror: Reflections on the Irish Fantastic from Sheridan Le Fanu to John Banville." Nordic Irish Studies 1 (2002): 51-61. Print.

Kant, Immanuel. "The Critique of Judgement." Continental Aesthetics: Romanticism to Postmodernism: An Anthology. Ed. Richard Kearney and David Rasmussen. Oxford: Blackwell, 2001. 5-42. Print.

Lewis, C.S. Experiment in Criticism. Cambridge: Cambridge UP, 1992. Print.

Lovecraft. H.P. “Supernatural Horror in Literature.” 2001. Web. 1 Mar. 2011.

Maupassant, Guy de. The Horla and Other Stories. Trans. Storm Jameson. New York: Knopf, 1925. Print.

---. The Horla and Other Stories. Trans. A.M.C. McMaster et al. Maryland: Wildside, 2007. Print.

Morris, David. B. "Gothic Sublimity." New Literary History 16.2 (1985): 299. Print.

Nelson, Dale. J. "Haggard's She: Burke's Sublime in a Popular Romance." Mythlore 24.3 (2006): 111-17. Print.

Poe, Edgar Allan. "The Philosophy of Composition." 1846. Web. 1 Mar. 2011.

Punter, David. The Modern Gothic. London: Longman, 1996. Print. Vol. 2 of The Literature of Terror. 2 vols. 1996.

Radcliffe, Ann. "On the Supernatural in Poetry." 1826. Web. 18 Nov. 2010. 
Sadner, David. The Fantastic in Literature: A Critical Reader. New York: Greenwood, 2004. Print.

---. The Fantastic Sublime: Romanticism and Transcendence in Nineteenth-Century Children's Literature. New York: Greenwood, 1996. Print.

Spencer, Kathleen. "Purity and Danger: Dracula, the Urban Gothic, and the Late Victorian Degeneracy Crisis." ELH 59.1 (Spring 1992): 197-225. Print.

Todorov, Tzvetan. The Fantastic: A Structural Approach to a Literary Genre. Trans. Richard Howard. London: Case Western Reserve UP, 1972. Print.

Varma, Devendra. P. The Gothic Flame: Being a History of the Gothic Novel in England: Its Origin, Efflorenscence, Disintegration and Residuary Influences. London: Barker, 1957. Print.

Wisker, Gina. Horror Fiction: An Introduction. New York: Continuum, 2005. Print.

Žižek, Slavoj. The Sublime Object of Ideology. London: Verso, 1998. Print. 